\title{
Other Nutrients and Dissolved Oxygen and Climate Change
}

\section{Keywords}

Nitrogen, phosphorus, silicate, iron, oxygen, $\mathrm{N}_{2}$ fixation, denitrification, de-oxygenation, hypoxia, anoxia

\section{Definition}

Primary and secondary production in the ocean depends on the supply of a few key elements. A combination of physical, chemical and microbial processes mediates the cycling of these elements through the environment and determines their supply. Anthropogenic perturbations to the cycles of these elements, either directly or through global warming, could result in severe alterations of patterns of primary production and a reorganization of marine ecosystems.

\section{Key Information}

\section{Cycling of Essential Elements in the Ocean}

The distribution and cycling of several key elements determines primaryand secondary production and biogeochemical processes in the ocean; of particular interest are nitrogen $(\mathrm{N})$, phosphorus $(\mathrm{P})$, silicon $(\mathrm{Si})$, oxygen $(\mathrm{O})$ and the trace metal iron (Fe).All marine organisms require $\mathrm{N}$ and $\mathrm{P}$ as essential building blocks of their lipids, proteins and carbohydrates. Si is only required by diatoms, a major group of unicellular marine algae that plays an important role in the biological carbon cycle. Diatom growth is typically limited by silicic acid.Fe is required only in trace amounts, but necessary for the synthesis of a range of essential enzymes including those used in the photosynthetic apparatus. Free oxygen $\left(\mathrm{O}_{2}\right)$, a by-product of photosynthesis, is essential for all multicellular heterotrophs and for many microbes as electron acceptor in the respiratory oxidation of organic matter. While there are other elements required for the synthesis of organic matter, cell walls, enzymes etc. (first and foremost carbon, but also sulfur, calcium, molybdenum and others), these elements are typically available in sufficient amountsthat their supply does not affect patterns of productivity in the modern ocean. Consequently anthropogenic perturbations in their cycling are not thought to be of first order importance.

The $\mathrm{N}$ cycle essentially consists of a numberof redox reactions that transform a variety of $\mathrm{N}$ species, ranging in oxidation state from -3 to 5 , from one form to another. The important inorganic species are the gaseous forms nitrogen gas $\left(\mathrm{N}_{2}\right)$ and nitrous oxide $\left(\mathrm{N}_{2} \mathrm{O}\right)$ and the dissolved forms nitrate $\left(\mathrm{NO}_{3}{ }^{-}\right)$and ammonium $\left(\mathrm{NH}_{4}^{+}\right)$. While $\mathrm{N}_{2}$ gas is extremely abundant, making up about $80 \%$ of Earth's atmosphere and representing $99 \%$ of all $\mathrm{N}$ in ocean and atmosphere combined, itis biologically unavailable to most microorganisms. Only a specialized group, referred to as $\mathrm{N}_{2}$ fixers or diazotrophs, is able to split the stable triple bond in the $\mathrm{N}_{2}$ molecule and reduce it to bioavailable ammonium, which is readily incorporated in the synthesis of organic matter (ammonium and organic matter represent the most reduced forms of $\mathrm{N}$ with an oxidation state of -3 ). This process is referred to as $\mathrm{N}_{2}$ fixation. In the presence of free oxygen, ammonium is oxidized to nitrate (the most oxidized from of $\mathrm{N}$ with an oxidation state of 5 ; nitrate is also bioavailable to most microorganisms) by chemoautotrophic bacteria in a process referred to as nitrification. In the present, well-oxygenated ocean theoverwhelming majority of bioavailable $\mathrm{N}$ is present in its oxidized form as nitrate. In the absence of oxygen, certain heterotrophic bacteria can use nitrate as electron acceptor instead of oxygen for the respiration of organic matter. This process is referred to as denitrification and one of its end products is $\mathrm{N}_{2}$. Denitrification thus represents a sink for bioavailable nitrogen. $\mathrm{N}_{2} \mathrm{O}$ is an intermediate product during nitrification and denitrification and only present in smallquantities, but is of interest because it is a potent greenhouse gas. In summary, the $\mathrm{N}$ cycle in the modern oceanis mediated by three key processes: $\mathrm{N}_{2}$ fixation, nitrification and denitrification, and is thus completely dependent on microbial activity. The balance of $\mathrm{N}_{2}$ fixation (source) and denitrification (sink) determines the oceanic reservoir of bioavailable nitrogen.

The cycling of $\mathrm{P}$ differs from that of $\mathrm{N}$ in the following two major aspects. There is no $\mathrm{P}$ in the atmosphere, and $\mathrm{P}$ is found 
in only one oxidation state, as phosphate $\left(\mathrm{PO}_{4}{ }^{-}\right)$. The oceanic reservoir of phosphate is determined by the balance of river inputs from rock weathering(source) and removal due to permanent burial of organic matter in sediments (sink). Both of these processes are slow, leading to a much larger turnover time for phosphatein the ocean than for nitrate.

The oceanic distributions of nitrate and phosphate are highly correlated and their relative proportion of about 16 atoms of $\mathrm{N}$ per 1 atom of $\mathrm{P}$ matches the average compositionof marine organic matter $\left(\mathrm{C}_{106} \mathrm{~N}_{16} \mathrm{P}_{1}\right)$ - an observation that was first articulated by Redfield in 1934 (the average relative ratios of elements in organic matter havesince been referred to as Redfield ratios). This remarkable correspondence can be explained by the interplay of $\mathrm{N}_{2}$ fixation and denitrification, which,in an oxygenated ocean and over sufficiently long time scales, will regulate the oceanic inventory of bioavailable $\mathrm{N}$ to match the $P$ inventory in terms of the Redfield ratio (Lenton and Watson 2000). In the modern ocean there is only a slight deficit in nitrate with respect to phosphate, so $\mathrm{N}$ is typically the element limiting marine primary production.

$\mathrm{Si}$ is required only by diatoms for their characteristic silica cell walls or frustules. Diatoms are very abundant and an important contributor to export of organic matter from the sunlit surface ocean to depth by sinking. Model-based estimates suggest that diatoms make up $40 \%$ of the global export of particulate organic carbon (Jin et al. 2006).

$\mathrm{Fe}$, although required in much smaller quantities than $\mathrm{N}, \mathrm{P}$ and $\mathrm{Si}$, is essential for many enzyme systems, incl. the photosynthetic apparatus and nitrogenase, the enzyme required for $\mathrm{N}_{2}$ fixation. Insufficient supply of Fe has been shown to limit primary production in the eastern equatorial Pacific, the subarctic Pacific and the Southern Ocean. These areas are the so-called high-nutrient, low-chlorophyll (or HNLC) regions, where unused nitrate and phosphate remain present in surface waters at the end of the growing season.

$\mathrm{O}_{2}$ is produced by photosynthesis and is consumed during aerobic respiration of organic matter (in terms of thermodynamic energy gain $\mathrm{O}_{2}$ is the most beneficial electron acceptor). About $20 \%$ of Earth's atmosphere consists of $\mathrm{O}_{2}$ , which accumulated after the evolution of oxygenic photosynthesis early in Earth's history because some reduced organic carbon was stored in sedimentary rocks (at the ocean floor and on continental cratons) and thus effectively removed from the reduction-oxidation cycle. The modern ocean is also well-oxygenated, with relatively small oxygen minimum zones and anoxia occurring only in isolated spots with restricted circulation, e.g., the Cariaco Basin, the Black Sea and the Baltic Sea. However, an oxygenated ocean is not an inevitable consequence of an oxygen-rich atmosphere. There have been extended periods throughout Earth's history when the ocean was anoxic (Fennel et al. 2005). Below the sunlit surface ocean the only source that offsets respiratory consumption of oxygen is physical transport of oxygenated water through convective mixing and thermohaline circulation. Since both of these physical processes are highly sensitive to climate, subsurface oxygen will likely be affected by climate change.

The cycles of N, P and $\mathrm{O}$ are linked and are also tightly coupled with the carbon cycle. One example illustrating the close coupling of N,P and carbon cyclingis the fact thatoceanic nitrate and phosphate are available almost in Redfield proportions, as mentioned above. This regulation of nitrate availability can however be disrupted by a decrease in the $\mathrm{O}_{2}$ supply as described below.

\section{Recent and Projected Changes}

Humans are massively perturbing the natural $\mathrm{N}$ cycle by adding bioavailable $\mathrm{N}$ through industrial $\mathrm{N}_{2}$ fixation for production of synthetic fertilizers, cultivation of leguminous crops and fossil fuel burning. By 1990 anthropogenic sources of bioavailable $\mathrm{N}$ had exceeded the rate of natural $\mathrm{N}_{2}$ fixation in the terrestrial biosphere as well as the rate of marine $\mathrm{N}_{2}$ fixation; by 2050 anthropogenic production of bioavailable $\mathrm{N}$ is projected to exceed natural terrestrial and oceanic $\mathrm{N}_{2}$ fixation combined (Galloway et al. 2004). While application of synthetic fertilizers is necessary to feed the growing world population, inequalities in its distribution and inefficiencies in its use are pervasive. Some regions lack sufficient fertilizer to meet even the most basic caloric demands of millions of people, while elsewhere an excess of food leads to unhealthy diets and fertilizers are appliedso inefficiently thatthey lead to eutrophication of aquatic environments (Galloway et al. 2008). Estimates suggest that about $80 \%$ of anthropogenic $N$ is denitrified in soils and freshwater systems and that the bulk of the remainder is denitrified on continental shelves (Fennel et al. 2006; Seitzinger et al. 2006). Hence river inputs of anthropogenic $\mathrm{N}$ are likely not an important nutrient source for the open ocean, yet lead to many negative effects in coastal waters including decreased water clarity, harmful algal blooms and an increasing occurrence of hypoxia and anoxia (Diaz and Rosenberg 2008).

In the open ocean global warming is expected to lead to stronger vertical density stratification and a slowdown of the 
thermohaline overturning circulation, both of which would result in a decrease in $\mathrm{O}_{2}$ supply to waters below the sunlit surface. Evidence of this de-oxygenation has already been reported (Stramma et al. 2008). If this trend continues, implications could be severe for deep-sea animals, especially benthic organisms with limited mobility. Ocean de-oxygenation would also have biogeochemical consequences. In a hypoxic or anoxic ocean, denitrification would become more important as a pathway for the respiration of organic matter compared to aerobic respiration, which could result in a larger loss of bioavailable $\mathrm{N}$ than can be replenished by $\mathrm{N}_{2}$ fixation. This, consequently, would decrease the inventory of bioavailable $\mathrm{N}$ and reduce primary productionglobally. A massive increase in denitrification could also result in a significant additional source of the greenhouse gas $\mathrm{N}_{2} \mathrm{O}$ to the atmosphere, further amplifying global warming.

Direct natural perturbations to the cycling of $\mathrm{P}, \mathrm{Si}$ and $\mathrm{Fe}$ are possible but would likely be smaller, at least over the next few hundred years. While dissolution and weathering of rocks is affected by climate (faster in warmer and more humid conditions), weathering rates are comparatively small. An expansion of arid regions and increase in the frequency of storms could accelerate Fe supply to the ocean, but this prediction is speculative. Variations in atmospheric Fe deposition to the ocean are thought to have occurred in concert with glacial/interglacial cycles in the past. In fact, these variations in Fe supply have been suggested to explain the glacial/interglacial changes in partitioning of carbon between the atmosphere and ocean (Martin 1990), which has prompted geo-engineering proposals to apply large-scale fertilization of the ocean with Fein order to mitigate future warming. Given the tight coupling of elemental cycles and the likelihood for unintended consequences,such proposals should be treated with caution.

\section{References}

Diaz RJ,and Rosenberg R (2008)Spreading Dead Zones and Consequences for Marine Ecosystems. Science321:926-929.

FennelK, Follows M, and Falkowski PG (2005) The co-evolution of the nitrogen, carbon and oxygen cycles in the Proterozoic Ocean.American Journal of Science 305:526-545

FennelK, Wilkin J, Levin J, Moisan J, O'Reilly J, Haidvogel D (2006) Nitrogen cycling in the Mid Atlantic Bight and implications for the North Atlantic nitrogen budget: Results from a three-dimensional model.Global Biogeochemical Cycles 20, GB3007, doi:10.1029/2005GB002456.

Galloway JN, Dentener FJ, Capone DG, Boyer EW, Howarth RW, Seitzinger SP, Asner GP, Cleveland CC, Green, PA, Holland EA, Karl DM, Michaels AF, Porter JH, Townsend AR, and Vörösmarty CJ(2004) Nitrogen cycles: Past, present, and future. Biogeochemistry 70:153-226

Galloway JN, Townsend AR, Erisman JW, Bekunda M, Cai Z, Freney JR, Martinelli LA, Seitzinger SP, and Sutton MA (2008) Transformation of the Nitrogen Cycle: Recent Trends, Questions, and Potential Solutions. Science 320:889-892

Jin X, Gruber N, Dunne JP, Sarmiento JL, and Armstrong RA (2006) Diagnosing the contribution of phytoplankton functional groups to the production and export of particulate organic carbon, $\mathrm{CaCO}$, and opal from global nutrient and alkalinity distributions.Global Biogeochemical Cycles 20, GB2015, doi:10.1029/2005GB002532.

Lenton TM, and Watson AJ (2000) Redfield revisited 1. Regulation of nitrate, phosphate, and oxygen in the ocean. Global Biogeochemical Cycles 14(1):225-248

Martin JH (1990) Glacial-interglacial $\mathrm{CO}_{2}$ change: The iron hypothesis. Paleoceanography 5(1):1-13

Redfield AC (1934) On the proportions of organic derivations in sea water and their relation to the composition of plankton. In: Daniel RJ (ed) James Johnstone Memorial Volume. University Press of Liverpool, pp. 176-192

Seitzinger S, Harrison JA, Böhlke JK, Bouwman AF, Lowrance R., Peterson B, Tobias C, Van Drecht G (2006) Denitrification across landscapes and waterscapes: A synthesis. Ecological Applications 16(6):2064-2090

Stramma L, Johnson GC, Sprintall J, and Mohrholz V (2008) Expanding oxygen-minimum zones in the tropical oceans. Science 320:655-658

\section{Cross-references}

Ecological carbon sequestration in the ocean

Marine productivity 


\section{Additional recommended reading}

Capone DG, Bronk DA, Mulholland MH, and Carpenter EJ (2008) Nitrogen in the Marine Environment $\left(2^{\text {nd }}\right.$ ed), Academic Press

Jacobson MC, Charlson RJ, Rodhe H, and Orians GH (2000) Earth system science, Academic Press

Sarmiento JL, and Gruber N (2006) Ocean biogeochemical dynamics, Princeton University Press

\section{Other Nutrients and Dissolved Oxygen and Climate Change}

Dr. Katja Department of Oceanography Dalhousie University 1355 Oxford, Room 2634 LSC, Fennel Halifax, Canada

DOI: $\quad 10.1007 /$ SpringerReference_306841

URL: $\quad$ http://www.springerreference.com/index/chapterdbid/306841

Part of: $\quad$ Global Environmental Change

Editor: $\quad$ Dr. Bill Freedman

PDF created on:

August, 09, 2013 09:11

(C) Springer-Verlag Berlin Heidelberg 2013 